\title{
Soil nitrogen availability in olive orchards after mulching legume cover crop residues
}

\author{
M. Ângelo Rodrigues ${ }^{\mathrm{a}, *}$, Carlos M. Correia ${ }^{\mathrm{b}}$, Ana Marília Claroc ${ }^{\mathrm{c}}$, Isabel Q. Ferreira ${ }^{\mathrm{c}}$, \\ José C. Barbosa ${ }^{\mathrm{a}}$, José M. Moutinho-Pereira ${ }^{\mathrm{b}}$, Eunice A. Bacelar ${ }^{\mathrm{b}}$, \\ Anabela A. Fernandes-Silva ${ }^{b}$, Margarida Arrobas ${ }^{a}$ \\ a Mountain Research Centre - Polytechnic Institute of Bragança, Campus de Santa Apolónia, Ap. 1152, 5301-855 Bragança, Portugal

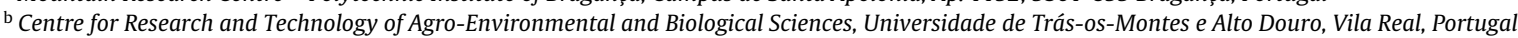 \\ c Polytechnic Institute of Bragança, Campus de Santa Apolónia, Ap. 1152, 5301-855 Bragança, Portugal
}

\section{A R T I C L E I N F O}

\section{Article history:}

Received 21 January 2013

Received in revised form 22 April 2013

Accepted 26 April 2013

\section{Keywords:}

Soil N dynamic

In situ incubation

Capped tubes

Olea europaea

Hairy vetch

White lupine

\begin{abstract}
A B S T R A C T
A natural source of nitrogen $(\mathrm{N})$ is needed to increase soil fertility in traditional olive orchards and to maintain the N nutritional status of olive trees. With this aim, we studied the introduction of legume cover crops in two olive orchards, which were converted into mulches and left on the ground as phytomass after they had been cut. The experiments were carried out in Suçães and Qta do Carrascal, NE Portugal, from October 2009 to January 2012. In Suçães, the ground-cover treatments were lupine (Lupinus albus L.), a mixture of 11 self-reseeding annual legume species, natural vegetation fertilized with $60 \mathrm{~kg} \mathrm{~N} \mathrm{hm}^{-2}$ and natural vegetation not fertilized. The treatments imposed in Qta do Carrascal were lupine, hairy vetch (Vicia villosa Roth.), a mixture of 11 self-reseeding annual legumes and natural vegetation. Soil $\mathrm{N}$ availability in the year following the establishment of the mulches was monitored by an in situ incubation technique. Olive yields and tree nutritional status were also measured. A peak of net $\mathrm{N}$ mineralization was recorded early in the autumn in the plots where the legume cover crops had been grown in the last season, in comparison with the natural vegetation plot. In the next spring, soil $\mathrm{N}$ availability was negligible even in the plots previously cropped with legume species. The effect of the legume cover crops on soil inorganic-N availability seems to have been slight and short-lived taking into account the high amounts of $\mathrm{N}$ contained in the mulched phytomass. The effect of legume cover crops on olive yield and leaf $\mathrm{N}$ concentration was statistically significant only in few occasions. The results of these experiments recommended some caution in the management of pure legume cover crops as a mulch in olive orchards due to the reduced transfer of $\mathrm{N}$ from legumes to olive trees.
\end{abstract}

(C) 2013 Elsevier B.V. All rights reserved.

\section{Introduction}

Nitrogen is the most frequently deficient nutrient in nonlegume cropping systems (Havlin et al., 2005). The dynamic of $\mathrm{N}$ in the soil-plant system often does not allow its accumulation in the soils in forms readily usable by plants. This requires that $\mathrm{N}$ has to be applied every growing season to supplement the lack of naturally available $\mathrm{N}$ in soils. The high crop response usually observed after $\mathrm{N}$ application has encouraged an excessive use of $\mathrm{N}$-fertilizers in agriculture, reducing $\mathrm{N}$ use efficiency and causing diverse environmental problems (Raun and Schepers, 2008). The high price of

\footnotetext{
* Corresponding author. Tel.: +351 273 303237; fax: +351 273325405. E-mail addresses: angelor@ipb.pt (M.Â. Rodrigues),ccorreia@utad.pt (C.M. Correia), efmarilia@hotmail.com (A.M. Claro), isabelaqferreira@gmail.com (I.Q. Ferreira), bb@ipb.pt (J.C. Barbosa), moutinho@utad.pt (J.M. Moutinho-Pereira), areal@utad.pt (E.A. Bacelar), anaaf@utad.pt (A.A. Fernandes-Silva), marrobas@ipb.pt (M. Arrobas).
}

$\mathrm{N}$ and the environmental issues have been pressing for the development of more sustainable farming systems with less reliance on synthetic- $\mathrm{N}$ fertilizers.

A reduction in the use of expensive off-farm inputs is of particular importance in marginal agricultural lands, such as the rainfed olive orchards of the Mediterranean basin, having a weak response to external inputs and low returns. Nevertheless, a source of $\mathrm{N}$ is always needed, either mineral or organic, without which there will be no proper crop growth and yield. Commercial organic fertilizers are not a solution that could be used widely. Their availability in the market is limited and their prices are high in comparison to their agronomic value (Rodrigues et al., 2006). Farmyard manures and other agricultural and livestock wastes are important fertilizer resources that can fully or partially balance the lack of $\mathrm{N}$ in agricultural soils. However, due to the specialization of the agricultural and livestock activities, occurring mainly in the twentieth century, there is a great distance between the sources of organic waste and the soils where they could be recycled. There are nowadays huge 
environmental problems in regions of intensive livestock production caused by an excessive use of animal waste as a fertilizer (Burton, 2009; Centner, 2011), and, on the other hand, large areas of agriculture where there are not any significant available on-farm sources of organic matter to apply to the soil. In the latter case, a natural source of $\mathrm{N}$ must be sought. Legume species, for instance, are able to fix atmospheric $\mathrm{N}$, meeting their own needs and transferring $\mathrm{N}$ to a non-legume crop after their $\mathrm{N}$-rich tissues have been mineralized (De Varennes et al., 2007; Russelle, 2008). Legume species can be grown either as main crops in rotation and/or as cover crops or green manures in annual and perennial tree crops.

Organic N sources, such as manures or green manures, are more difficult to manage than the inorganic-N fertilizers, since it is very difficult to predict when their $\mathrm{N}$ will become available in the soil. The mineralization of the organic substrates depends on their composition, the C:N ratio in particular (Paul and Clark, 1996; Havlin et al., 2005), and on the environmental conditions affecting microbial activity, such as temperature (Jenkinson and Ayanaba, 1977; Gaiser et al., 1994) and soil moisture (Stanford and Epstein, 1974), making the process unpredictable. It may be, for example, that the $\mathrm{N}$ release from the organic residues is not coincident with the periods of active nutrient uptake by the non-legume crops. Furthermore, in particular situations, the environmental damage of using these organic residues can be of similar concern as that associated with the use of synthetic-N fertilizers (Beegle et al., 2008; Sims and Stehouwer, 2008).

In situ incubation methods have been used in the past to monitor $\mathrm{N}$ flows in soils under field conditions. They can provide information about the time and rate in which $\mathrm{N}$ becomes available in the soil, determining its agronomic and environmental value. The buried polyethylene bag (Eno, 1960; Monaco et al., 2010) and capped PVC or metallic tubes (Raison et al., 1987; Subler et al., 1995; Durán et al., 2012) methods have been the most widely used. Many others, however, have interesting features. An incubation technique using ion exchange resins below intact soil cores for adsorbing inorganic-N leached from the core was used by $\mathrm{Di}$ Stefano and Gholz (1986) and Wienhold (2007). Hatch et al. (1990) and Bhogal et al. (1999) incubated soil cores in the field in sealed containers with acetylene to inhibit nitrification and thereby minimize losses of $\mathrm{N}$ through denitrification to better measure net rates of mineralization. Rodrigues (2004) incubated soil cores collected by PVC tubes in glass jars buried in the soil to simplify the sampling process and increase the field replications. In general, the techniques using undisturbed soil cores provide reliable quantitative estimates of $\mathrm{N}$ transformations in the soil (Raison et al., 1987; Hook and Burke, 1995).

In this study, several legume cover crops were grown in two olive orchards in NE Portugal in an attempt to supply the $\mathrm{N}$ needs for the trees. The legume species were cut in spring and left on the ground as a mulch. This would avoid soil tilling and eliminate the consequent damage of the olive tree roots. The dynamic of $\mathrm{N}$ in the soil in the year after the establishment of the mulches was monitored by using an in situ incubation technique. The effect of the ground-cover treatments on olive yield and $\mathrm{N}$ nutritional status of trees was also determined as an indirect measure of the transfer of $\mathrm{N}$ from legumes to olive trees. It is expected that using all these sources of information it will be possible to draw a reliable picture of what happened in the soil when the legume cover crop residues are left on the ground as a mulch.

\section{Materials and methods}

\subsection{Site characterization}

Two field experiments were carried out in Suçães, Mirandela $\left(41^{\circ} 29^{\prime} \mathrm{N}, 7^{\circ} 15^{\prime} \mathrm{W}\right)$, and Qta do Carrascal, Vila Flor ( $41^{\circ} 16^{\prime} \mathrm{N}, 7^{\circ}$

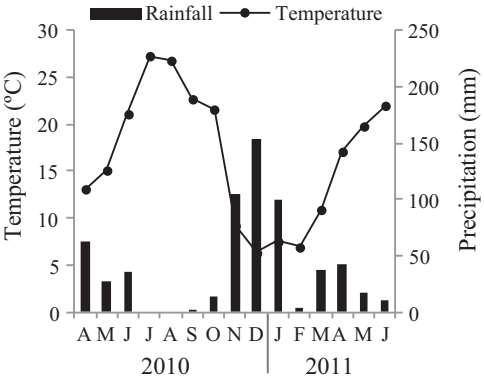

Fig. 1. Mean daily temperature and monthly precipitation from April 2010 to June 2011 recorded at a weather station located in Carrascal, Vila Flor.

$5^{\prime} \mathrm{W}$ ), in NE Portugal. The region benefits from a Mediterranean type climate with average annual temperature and precipitation of $14.3^{\circ} \mathrm{C}$ and $509 \mathrm{~mm}$, respectively. Weather data recorded in Qta do Carrascal during the experimental period are presented in Fig. 1. The orchard of Suçães was $\sim 20$ years old, the olive trees of cv. Cobrançosa and rainfed managed. The soil is a Leptosol derived from schist, sandy loam ( $13.1 \%$ clay, $26.6 \%$ silt, $60.3 \%$ sand ) textured, $\mathrm{pH}\left(\mathrm{H}_{2} \mathrm{O}\right) 4.1$, organic carbon (C) $7.9 \mathrm{~g} \mathrm{~kg}^{-1}$ and extractable phosphorus (P) and potassium (K) (Egner-Riehm) 21.0 and $96.3 \mathrm{mg} \mathrm{kg}^{-1}$, respectively. In the years before the establishment of the experiment, the farmer used to control the weeds through an annual application of a glyphosate-based herbicide, usually applied in May. The farmer also used to apply the fertilizers beneath the trees' canopy at rates equivalent to $60 \mathrm{~kg} \mathrm{~N}, \mathrm{P}_{2} \mathrm{O}_{5}$ and $\mathrm{K}_{2} \mathrm{O} \mathrm{hm}^{-2}$ and $15 \mathrm{~g} \mathrm{~B}$ per tree. Shortly before the trial started $1500 \mathrm{~kg} \mathrm{hm}^{-2}$ of lime $(88 \%$ $\mathrm{CaCO}_{3}$ and $\left.5 \% \mathrm{MgCO}_{3}\right)$ and $250 \mathrm{~kg} \mathrm{hm}^{-2}$ of superphosphate $(18 \%$ $\mathrm{P}_{2} \mathrm{O}_{5}$ ) were applied. The orchard of Qta do Carrascal was $\sim 15$ years old and the olive trees of cv. Negrinha de Freixo. It is drip-irrigated and organically managed. The soil is also a Leptosol derived from schist. The texture is sandy loam ( $11.8 \%$ clay, $32.0 \%$ silt, $56.2 \%$ sand $)$, $\mathrm{pH}\left(\mathrm{H}_{2} \mathrm{O}\right) 5.7$, organic $\mathrm{C} 8.3 \mathrm{~g} \mathrm{~kg}^{-1}$ and extractable P and $\mathrm{K} 33.2$ and $41.5 \mathrm{mg} \mathrm{kg}^{-1}$, respectively. In the years before the establishment of the experiment, the farmer used to control the weeds by tillage. The fertilization regime usually used by the farmer consisted of the application of a small amount of on-farm compost, supplemented by one or two applications per year of foliar sprays or soluble fertilizers in irrigation water. After the trial started, no fertilizers were added to the trees.

\subsection{Experimental layout and orchard management}

In each olive orchard four different ground-cover treatments were imposed. In each orchard there were delimited four plots of 0.4 and $0.6 \mathrm{hm}^{-2}$, respectively in Suçães and Carrascal. The treatments laid out in the Suçães orchard were: lupine; a mixture of 11 pasture legumes (Ornithopus compressus L. cv. Charano; O. sativus Brot. cvs. Erica and Margurita; Trifolium subterraneum L. ssp subterraneum Katzn. and Morley cvs. Dalkeith, Seaton Park, Denmark and Nungarin; T. resupinatum L. ssp resupinatum Gib and Belli cv. Prolific; T. incarnatum L. cv. Contea; T. michelianum Savi cv. Frontier; and Biserrula pelecinus L. cv. Mauro); natural vegetation fertilized with $60 \mathrm{~kg} \mathrm{~N} \mathrm{hm}^{-2}$ (ammonium nitrate, 20.5\% N, spread evenly throughout the plot area with a centrifugal seeder); and natural vegetation left unfertilized. The treatments applied in the Carrascal experiment were: lupine, a mixture of 11 pasture legumes (the same of Suçães); hairy vetch; and natural vegetation not fertilized. The legume cover crops were sown in October 14th, 2009. Lupine and hairy vetch were respectively seeded at rates of 180 and $30 \mathrm{~kg}$ seed hm $\mathrm{hm}^{-2}$. The mixture of the legume pasture species was sown at a rate of an 11th of that recommended for each individual species if it was seeded alone in pure culture. The sowing 
was done manually and the seeds of lupine and vetch incorporated in the soil by a cultivator, and the pasture legume species by a roller. In May 2010 the biomass of all the cover crops was destroyed with a rotary slasher and left on the ground as a mulch.

\subsection{Nitrogen recovery and C: $N$ ratio of cover crop residues}

Total dry mater (DM) yields of legume cover crops were determined from samples of $1 \mathrm{~m}^{2}$ and four replications per groundcover treatment. Subsamples of the phytomass were weighed, oven-dried at $70^{\circ} \mathrm{C}$, dry-weighed and ground. Carbon (C) and $\mathrm{N}$ concentrations in dried tissue samples were determined. Organic $\mathrm{C}$ was determined by the loss ignition technique, involving ashing a dry sample $\left(105^{\circ} \mathrm{C}\right.$ ) in a muffle furnace at $450^{\circ} \mathrm{C}$, (i.e. heating until the organic matter is burned away). Organic $\mathrm{C}$ $(\%)=(\mathrm{W} 105-\mathrm{W} 450) / \mathrm{W} 105 \times 0.58$ (Jones, 2001). Tissue N concentration was determined by a Kjeldahl method (Walinga et al., 1989) in a Velk Scientifica UDK 152 distillation and titration unit. DM yields and $\mathrm{N}$ concentrations allowed the estimation of crop $\mathrm{N}$ recoveries, $\mathrm{C}$ and $\mathrm{N}$ concentrations and the $\mathrm{C}: \mathrm{N}$ ratios of the crop residues.

\subsection{In situ soil incubation}

The incubation technique consisted of burying metallic tubes $(15 \mathrm{~cm}$ long and $6.3 \mathrm{~cm}$ internal diameter) by hammering them directly into the ground. The tubes have a sharp bevel to make the insertion in these shallow and hard soils easier, maintaining the bulk density of the incubating soil cores and a minimum soil disturbance. After the tubes had been buried, they were covered at the ground level with a piece of clay tile slightly larger than the circumference of the tube. The tile prevents the entry of rainwater inside the tubes and also the direct incidence of sunlight on the edge of metal that would modify the temperature regime of the incubating soil cores and the consequent disturbance to soil biological activity. The tile prevents also the growth of herbaceous vegetation inside the tube. At the end of each incubation period, the incubating soil cores were collected and the tubes inserted again in the ground. At the same time, fresh soil samples (not incubated) were also collected close to the place where the tubes were left for a new incubation period. The technique allows a sequential analysis of the soil $\mathrm{N}$ dynamic, in particular the estimation of net $\mathrm{N}$ mineralization, by comparing the inorganic- $\mathrm{N}$ levels in the incubated (time, $t$ ) and not incubated (time, $t_{-1}$ ) soil samples. Six replications per treatment were used in a total of 48 tubes in the two orchards.

All the soil samples, incubated and not incubated, were placed in a cooler as soon as possible after collection, and taken to the laboratory where they were stored frozen until analysis. The samples were field-moist sieved (6-mm mesh) and nitrate- $\mathrm{N}$ and ammonium-N were extracted with potassium chloride $(\mathrm{KCl})$. To prepare the extracts, $20 \mathrm{~g}$ of soil were shaken with $40 \mathrm{ml} 2 \mathrm{M} \mathrm{KCl}$ for an hour and filtered through a Watman \#42 filter paper. Nitrate and ammonium concentrations in the extracts were determined by UV-vis spectrophotometry. The moisture content of the soil samples was also determined by drying at $105^{\circ} \mathrm{C}$ to express the results on a dry soil basis.

\subsection{Olive yield and nitrogen nutritional status of trees}

The olive yields were recorded from eight and ten similar trees per treatment, respectively in the experiments of Suçães and Carrascal. In Suçães, the trees were harvested for three consecutive years, in the autumns of 2009, 2010 and 2011. The harvest of 2009 represents the year zero, since it was performed at the beginning of the experiment, before the effects of the treatments had manifested themselves. In the Carrascal experiment it was not possible to harvest in the autumn of 2009 . The olive yields were recorded only
Table 1

Dry matter yield (DMY), N recovery, carbon and nitrogen concentration in aboveground cover crop tissues and C: $\mathrm{N}$ ratios in the olive orchards of Suçães and Carrascal.

\begin{tabular}{llllll}
\hline Treatment & $\begin{array}{l}\text { DMY } \\
\left(\mathrm{Mg} \mathrm{hm}^{-2}\right)\end{array}$ & $\begin{array}{l}\text { N recovery } \\
\left(\mathrm{kg} \mathrm{hm}^{-2}\right)\end{array}$ & $\mathrm{C}\left(\mathrm{g} \mathrm{kg}^{-1}\right)$ & $\mathrm{N}\left(\mathrm{g} \mathrm{kg}^{-1}\right)$ & $\mathrm{C}: \mathrm{N}$ \\
\hline Suçães & & & & & \\
Lupine & $8.2 \mathrm{a}^{\mathrm{a}}$ & $194.6 \mathrm{a}$ & $555.5 \mathrm{a}$ & $23.8 \mathrm{a}$ & 23.3 \\
Pasture legs & $6.4 \mathrm{~b}$ & $119.2 \mathrm{~b}$ & $545.9 \mathrm{ab}$ & $17.1 \mathrm{~b}$ & 31.9 \\
Nat veg +N & $1.1 \mathrm{C}$ & $23.9 \mathrm{C}$ & $538.0 \mathrm{~b}$ & $20.8 \mathrm{ab}$ & 25.9 \\
Nat veg $-\mathrm{N}$ & $0.7 \mathrm{c}$ & $7.1 \mathrm{~d}$ & $541.9 \mathrm{~b}$ & $10.4 \mathrm{c}$ & 52.1 \\
Carrascal & & & & & \\
Lupine & $6.9 \mathrm{a}$ & $138.5 \mathrm{a}$ & $552.8 \mathrm{a}$ & $20.1 \mathrm{~b}$ & 27.5 \\
Pasture legs & $5.6 \mathrm{a}$ & $105.3 \mathrm{a}$ & $529.3 \mathrm{~b}$ & $19.0 \mathrm{~b}$ & 27.9 \\
Hairy vetch & $5.9 \mathrm{a}$ & $155.7 \mathrm{a}$ & $530.2 \mathrm{~b}$ & $26.0 \mathrm{a}$ & 20.4 \\
Nat veg -N & $1.1 \mathrm{~b}$ & $11.4 \mathrm{a}$ & $531.1 \mathrm{~b}$ & $10.0 \mathrm{c}$ & 53.1 \\
\hline
\end{tabular}

a Means followed by the same letter in columns, and for each orchard, are not different by Tukey HSD test $(\alpha=0.05)$.

in the autumns of 2010 and 2011. The harvest in Suçães was performed by a trunk shaker head which detaches the olives which are collected by an associated inverted umbrella system. In Carrascal, the olives were harvested with a portable branch shaker. The device pulls the fruits down which were recovered in a sheet spread on the floor. In the Carrascal experiment the trunk circumference of the trees was also measured at the beginning (October 2009) and at the end (October 2011) of the experimental period. The circumference of the trunk was measured at $40 \mathrm{~cm}$ above ground.

$\mathrm{N}$ concentration in olive fruit parts (pulp and pit) was determined from the olive samples of the harvest of 2010. Samples of 50 olives were weighed green, and divided into pulp and pit. The pulp was removed from pit and part of it was used green for nutrient determination since the fat of the fruits does not allow them to be ground. The water content was determined thereafter in the remaining pulp to express the results on a DM basis. The pits were oven-dried at $70^{\circ} \mathrm{C}$, hammered and ground (Rodrigues et al., 2012). Nitrogen concentration was determined as described above for legume cover crop residues.

The $\mathrm{N}$ nutritional status of olive trees was monitored by leaf analysis. Leaf samples were collected by the standard procedure (Freeman et al., 2005) on five dates, January and July 2010, January and July 2011 and January 2012. The leaf samples were oven-dried at $70^{\circ} \mathrm{C}$ and ground. Leaf $\mathrm{N}$ concentration was determined by a Kjeldahl method as described above.

\subsection{Statistical analysis}

Data analysis was carried out using JMP software. A completely randomized design with a single factor (soil management) was used to compare the population means (Ott and Longnecker, 2001). We assume that there is little variability associated with soil fertility and trees. After ANOVA examination, the means with significant differences $(P<0.05)$ were separated by the Tukey HSD test $(\alpha=0.05)$.

\section{Results}

Dry matter yields of cover crops legumes ranged from 5.6 to $8.2 \mathrm{Mg} \mathrm{hm}^{-2}$ between legume species and $0.7-1.1 \mathrm{Mg} \mathrm{hm}^{-2}$ in natural vegetation plots even in the fertilized one (Table 1 ). $\mathrm{N}$ recovered by the legume cover crops reached 194.6 and $110.2 \mathrm{~kg} \mathrm{hm}^{-2}$, respectively in lupine and pasture legume plots of the Suçães experiment, whereas unfertilized natural vegetation recovered only $7.1 \mathrm{~kg} \mathrm{~N} \mathrm{hm}^{-2}$. In Carrascal, lupine, pasture legumes, hairy vetch and natural vegetation recoveries, were respectively, 138.5, $105.3,155.7$ and $11.4 \mathrm{~kg} \mathrm{~N} \mathrm{hm}^{-2}$. C concentrations varied significantly among cover crops. In Suçães the lowest and the highest 

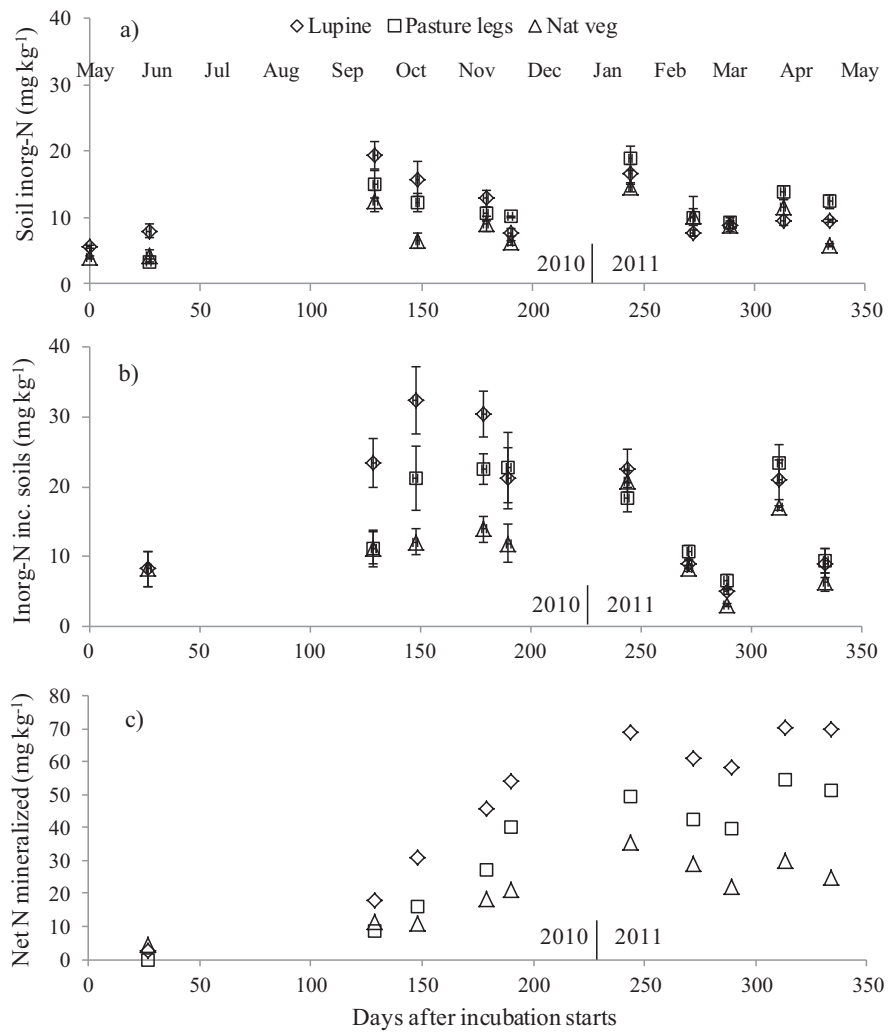

Fig. 2. Soil inorganic $N$ in (a) fresh, (b) incubated soil samples and (c) net $N$ mineralized (inorganic- $\mathrm{N}$ in incubated samples at time $t_{1}$ - inorganic- $\mathrm{N}$ in fresh samples in time $t_{-1}$ ) from May 2010 to May 2011 in the Suçães olive orchard following the cover crop treatments. The line segments represent the mean confidence intervals $(\alpha=0.05)$.

values were 538.0 and $555.5 \mathrm{~g} \mathrm{~kg}^{-1}$, respectively for Nat veg $+\mathrm{N}$ and lupine plots. In Carrascal, C concentrations varied from 529.3 to $552.8 \mathrm{~g} \mathrm{~kg}^{-1}$ for pasture legume and lupine plots. In Suçães, $\mathrm{N}$ concentrations varied from 10.4 to $23.8 \mathrm{~g} \mathrm{~kg}^{-1}$, respectively in natural vegetation and lupine plant tissues. In Carrascal, the higher tissue $\mathrm{N}$ concentrations were found for vetch $\left(26.0 \mathrm{~g} \mathrm{~kg}^{-1}\right)$. The higher $\mathrm{C}: \mathrm{N}$ ratios were found in unfertilized natural vegetation $(\sim 52-53)$ and the lower values in vetch tissues (20.4). The natural vegetation fertilized with $\mathrm{N}$ in the Suçães experiment showed a C:N ratio (25.9) similar to that found in the legume cover crops (20.4-31.9).

The analysis of fresh soil samples of the incubation trial of Suçães revealed a small peak of inorganic- $N$ in the soil in June 2010 in the plots previously cropped with lupine (Fig. 2a). The soil inorganic-N levels in the fresh soil samples continued to rise until the early autumn, in particular in the lupine plot. Thereafter, the soil inorganic-N levels dropped until the early winter. In the autumn, the highest values were recorded in the lupine plot while in winter and early spring they were found in the pasture legume plot. The natural vegetation plot almost always registered the lower inorganic-N levels in fresh soil samples. Soil inorganic-N levels in incubated soil samples followed the same general pattern observed in the fresh samples (Fig. 2b). A high peak of soil inorganic-N was observed in autumn, in particular in the lupine plot. However, contrary to what was observed in fresh soil samples, the inorganic-N levels persisted high throughout the autumn. In winter and spring, the values from the lupine and pasture legume plots were only slightly higher than those observed in the natural vegetation plot. Total net $\mathrm{N}$ mineralization from the lupine plot was the highest in comparison to the other treatments due to the peak observed in autumn (Fig. 2c). The natural vegetation plot registered the lowest values. At the end of the season, the total net $\mathrm{N}$ mineralized
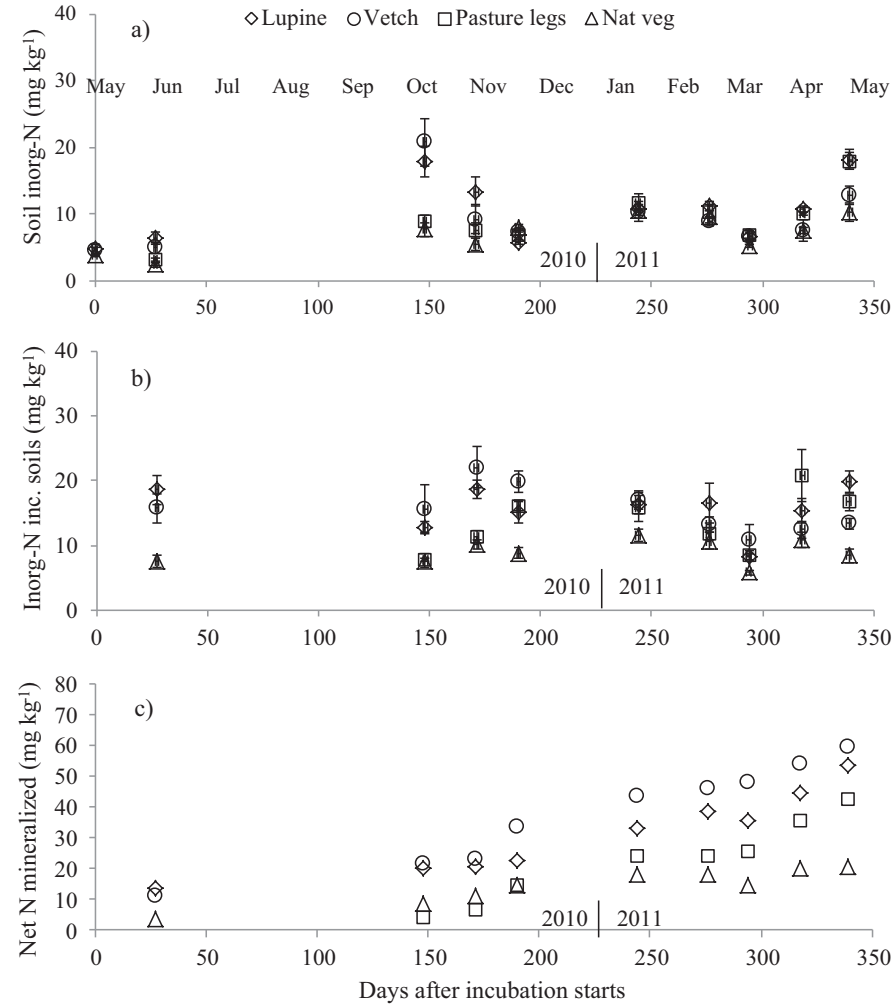

Fig. 3. Soil inorganic $N$ in (a) fresh, (b) incubated soil samples and (c) net $N$ mineralized (inorganic- $\mathrm{N}$ in incubated samples at time $t_{1}$ - inorganic- $\mathrm{N}$ in fresh samples in time $t_{-1}$ ) from May 2010 to May 2011 in the Carrascal olive orchard following the cover crop treatments. The line segments represent the mean confidence intervals $(\alpha=0.05)$.

in the lupine and pasture legume plots amounted, respectively, to 45 and $16 \mathrm{mg} \mathrm{kg}^{-1}$ more than the values recorded from the natural vegetation plot.

The fresh soil samples of Carrascal showed a peak of inorganic$\mathrm{N}$ in the autumn mainly from the plots of hairy vetch and lupine and another peak in May led by the samples collected from lupine and pasture legume plots (Fig. 3a). Data from incubated soil samples peaked at three times, in spring and autumn 2010 and spring 2011 (Fig. 3b). The values of inorganic-N from incubated samples were usually higher than those from fresh samples. Inorganic$\mathrm{N}$ levels in the natural vegetation plot were usually lower than those found in the other soil management treatments. Total net $\mathrm{N}$ mineralized during the entire growing season amounted to $38.8,32.8$ and $21.6 \mathrm{mg} \mathrm{kg}^{-1}$ more than the values recorded from the natural vegetation plot, respectively in hairy vetch, lupine and pasture legumes plots (Fig. $3 \mathrm{c}$ ). These values represent the contribution of the legume residues to the net balance of the mineralization-immobilization process.

From the fresh soil samples it was observed that the contribution of nitrate- $\mathrm{N}$ form to total inorganic- $\mathrm{N}$ was almost twice that of the contribution of ammonium-N form (data not shown). In the Suçães experiment, the fraction of $\mathrm{NH}_{4}^{+}-\mathrm{N}$ form represented $36.7 \%$ of the total inorganic- $\mathrm{N}$ considering all sampling dates, and in Carrascal this value averaged $35.6 \%$. A peak in inorganic- $\mathrm{N}$ form was usually due to a proportional increment in the nitrate-N and ammonium-N forms. In the incubated soil samples the pattern of the contribution of $\mathrm{NO}_{3}^{-}-\mathrm{N}$ and $\mathrm{NH}_{4}^{+}-\mathrm{N}$ to inorganic- $\mathrm{N}$ was similar to that found in the fresh soil samples (data not shown).

In the experiment of Suçães, the olive yields in the year zero (2009) were not statistically different between the ground-cover treatments (Table 2) due to the previous selection of the size of the olive trees. In the first year after the legume cover crops had 
Table 2

Olive yields in three consecutive harvests in the Suçães olive orchard and accumulated olive yields, as the sum of the second and third harvests $(2010+2011)$

\begin{tabular}{lllll}
\hline Treatment & $\begin{array}{l}24 \text { Nov, 2009 } \\
\left(\mathrm{kg} \mathrm{tree}^{-1}\right)\end{array}$ & $\begin{array}{l}24 \text { Nov, 2010 } \\
\left(\text { kg tree }^{-1}\right)\end{array}$ & $\begin{array}{l}17 \text { Nov, 2011 } \\
\left(\mathrm{kg} \mathrm{tree}^{-1}\right)\end{array}$ & $\begin{array}{l}\text { Accumulated } \\
\left(\mathrm{kg} \mathrm{tre}^{-1}\right)\end{array}$ \\
\hline Lupine & $13.0 \mathrm{a}^{\mathrm{a}}$ & $20.8 \mathrm{ab}$ & $14.3 \mathrm{a}$ & $35.1 \mathrm{a}$ \\
Pasture legs & $14.0 \mathrm{a}$ & $23.1 \mathrm{a}$ & $16.0 \mathrm{a}$ & $39.1 \mathrm{a}$ \\
Nat veg +N & $13.3 \mathrm{a}$ & $19.9 \mathrm{ab}$ & $15.6 \mathrm{a}$ & $35.5 \mathrm{a}$ \\
Nat veg $-\mathrm{N}$ & $12.9 \mathrm{a}$ & $17.6 \mathrm{~b}$ & $12.5 \mathrm{a}$ & $30.1 \mathrm{a}$ \\
\hline
\end{tabular}

a Means followed by the same letter in columns are not different by Tukey HSD test $(\alpha=0.05)$.

Table 3

Olive yields in two consecutive harvests in the Carrascal olive orchard, accumulated olive yields as the sum of the two harvests $(2010+2011)$ and increase in trunk circumference between October 2009 and October 2011.

\begin{tabular}{lllll}
\hline Treatment & $\begin{array}{l}\text { 03 Dec, 2010 } \\
\left(\mathrm{kg} \mathrm{tree}^{-1}\right)\end{array}$ & $\begin{array}{l}30 \text { Nov, 2011 } \\
\left(\mathrm{kg} \mathrm{tree}^{-1}\right)\end{array}$ & $\begin{array}{l}\text { Accumulated } \\
\left(\mathrm{kg} \mathrm{tree}^{-1}\right)\end{array}$ & $\begin{array}{l}\Delta \text { Trunk } \\
(\mathrm{cm})\end{array}$ \\
\hline Lupine & $18.5 \mathrm{a}^{\mathrm{a}}$ & $1.9 \mathrm{a}$ & $20.4 \mathrm{a}$ & $4.2 \mathrm{a}$ \\
Pasture legs & $14.1 \mathrm{a}$ & $2.6 \mathrm{a}$ & $16.7 \mathrm{a}$ & $4.1 \mathrm{a}$ \\
Vetch & $16.1 \mathrm{a}$ & $2.7 \mathrm{a}$ & $18.8 \mathrm{a}$ & $4.2 \mathrm{a}$ \\
Nat veg & $12.9 \mathrm{a}$ & $1.9 \mathrm{a}$ & $14.8 \mathrm{a}$ & $3.8 \mathrm{a}$ \\
\hline
\end{tabular}

a Means followed by the same letter in columns are not different by Tukey HSD test $(\alpha=0.05)$.

been established (2010) the means presented significant differences. The olive trees of the Nat veg $-\mathrm{N}$ plot produced the lowest values. The results of 2011 and the accumulated $(2010+2011)$ olive yields, revealed also lower values for the natural vegetation plot in comparison to the cultivated ones but the differences did not have statistical significance.

In the Carrascal experiment the results of the two available harvests showed that the mean olive yields of the natural vegetation plot were slightly lower than those of the other ground-cover treatments (Table 3), but not statistically different. The sums of the olive yields of the two harvests were $20.4,16.7,18.8$ and $14.8 \mathrm{~kg} \mathrm{tree}^{-1}$ respectively in lupine, pasture legumes, hairy vetch and natural vegetation plots. The increase in trunk circumference during the experimental period was also the lowest in the trees of the natural vegetation plot with a value of $3.8 \mathrm{~cm}$, whereas in the hairy vetch and lupine plots, it was $4.2 \mathrm{~cm}$. However, the means were not statistically different.

In the experiment of Suçães, $\mathrm{N}$ concentration in olive pulp varied from $5.8 \mathrm{~g} \mathrm{~kg}^{-1}$ in lupine plot to $4.8 \mathrm{~g} \mathrm{~kg}^{-1}$ in Nat veg $-\mathrm{N}$ plot, while $\mathrm{N}$ concentration in the pit varied from 4.8 to $3.1 \mathrm{~g} \mathrm{~kg}^{-1}$, respectively in Pasture legumes and Nat veg $-\mathrm{N}$ plots (Table 4). In Carrascal, $\mathrm{N}$ concentration in pulp varied from 5.6 to $4.1 \mathrm{k} \mathrm{kg}^{-1}$ in Nat veg $+\mathrm{N}$ and Nat veg $-\mathrm{N}$ plots and in pit varied from 6.2 to $5.2 \mathrm{~g} \mathrm{~kg}^{-1}$ in Nat $\mathrm{veg}+\mathrm{N}$ and $\mathrm{Nat}$ veg $-\mathrm{N}$ plots. The means were statistically different for $\mathrm{N}$ concentration in pit in Suçães and for $\mathrm{N}$ concentration in pulp in Carrascal.

The ground-cover treatments had an effect often statistically significant on leaf $\mathrm{N}$ concentration of olive trees (Table 5). The unfertilized natural vegetation plot usually showed significant

Table 4

Nitrogen concentration in the pulp and pit of olive fruits in the harvest of November 2010.

\begin{tabular}{llllll}
\hline Suçães & $\begin{array}{l}\text { Pulp } \\
\left(\mathrm{g} \mathrm{kg}^{-1}\right)\end{array}$ & $\begin{array}{l}\text { Pit } \\
\left(\mathrm{g} \mathrm{kg}^{-1}\right)\end{array}$ & Carrascal & $\begin{array}{l}\text { Pulp } \\
\left(\mathrm{g} \mathrm{kg}^{-1}\right)\end{array}$ & $\begin{array}{l}\text { Pit } \\
\left(\mathrm{g} \mathrm{kg}^{-1}\right)\end{array}$ \\
\hline Lupine & $5.8 \mathrm{a}^{\mathrm{a}}$ & $4.6 \mathrm{a}$ & Lupine & $5.0 \mathrm{ab}$ & $5.3 \mathrm{a}$ \\
Pasture legs & $5.5 \mathrm{a}$ & $4.8 \mathrm{a}$ & Annual legs & $4.5 \mathrm{~b}$ & $6.0 \mathrm{a}$ \\
Nat vet $+\mathrm{N}$ & $5.1 \mathrm{a}$ & $4.0 \mathrm{ab}$ & Vetch & $5.6 \mathrm{a}$ & $6.2 \mathrm{a}$ \\
Nat veg $-\mathrm{N}$ & $4.8 \mathrm{a}$ & $3.1 \mathrm{~b}$ & Nat veg & $4.1 \mathrm{~b}$ & $5.2 \mathrm{a}$ \\
\hline
\end{tabular}

a Means followed by the same letter in columns are not different by Tukey HSD test $(\alpha=0.05)$.
Table 5

Nitrogen concentration in olive leaves at five sampling dates as a function of the cover crop treatments, for the two orchards studied.

\begin{tabular}{lccccc}
\hline & Jan 2010 & Jul 2010 & Jan 2011 & Jul 2011 & Jan 2012 \\
\hline & & \multicolumn{2}{c}{$\left(\mathrm{g} \mathrm{kg}^{-1}\right)$} \\
Suçães & $14.9 \mathrm{a}^{\mathrm{a}}$ & $16.4 \mathrm{ab}$ & $14.4 \mathrm{a}$ & $12.3 \mathrm{a}$ & $13.5 \mathrm{ab}$ \\
Lupine & $15.1 \mathrm{a}$ & $16.7 \mathrm{a}$ & $14.7 \mathrm{a}$ & $12.0 \mathrm{ab}$ & $13.8 \mathrm{a}$ \\
Pasture legs & $14.8 \mathrm{a}$ & $16.7 \mathrm{a}$ & $14.9 \mathrm{a}$ & $11.9 \mathrm{ab}$ & $12.5 \mathrm{~b}$ \\
Nat veg +N & $14.5 \mathrm{a}$ & $16.1 \mathrm{~b}$ & $14.6 \mathrm{a}$ & $11.3 \mathrm{~b}$ & $11.1 \mathrm{c}$ \\
Nat veg -N & & & & & \\
Carrascal & & $13.8 \mathrm{a}$ & $14.2 \mathrm{ab}$ & $12.5 \mathrm{a}$ & $13.1 \mathrm{a}$ \\
Lupine & $14.7 \mathrm{a}$ & $12.2 \mathrm{~b}$ & $13.7 \mathrm{~b}$ & $12.7 \mathrm{a}$ & $14.2 \mathrm{a}$ \\
Pasture legs & $13.9 \mathrm{~b}$ & $13.8 \mathrm{a}$ & $15.8 \mathrm{a}$ & $12.9 \mathrm{a}$ & $13.2 \mathrm{a}$ \\
Vetch & $14.9 \mathrm{a}$ & $12.1 \mathrm{~b}$ & $13.5 \mathrm{~b}$ & $10.8 \mathrm{~b}$ & $12.9 \mathrm{a}$ \\
Nat veg & $13.9 \mathrm{~b}$ & &
\end{tabular}

a Means followed by the same letter in columns, and for each orchard, are not different by Tukey HSD test $(\alpha=0.05)$.

lower leaf $\mathrm{N}$ concentrations than the other treatments. The trees of the pasture legumes plot of the Carrascal experiment also often showed significant lower leaf $\mathrm{N}$ concentrations than that of the other legume cover crops. The trees of the plot receiving $60 \mathrm{~kg} \mathrm{~N} \mathrm{ha}^{-1}(\mathrm{Nat} \mathrm{Veg}+\mathrm{N})$ in the Suçães experiment showed leaf $\mathrm{N}$ concentrations not very dissimilar to that of the legume cover crop plots. Leaf $\mathrm{N}$ concentrations for all plots and sampling dates ranged from 10.8 to $16.7 \mathrm{~g} \mathrm{~kg}^{-1}$.

\section{Discussion}

From fresh and incubated soil samples a small peak in organic$\mathrm{N}$ was observed in June 2010, shortly after the cutting of the cover crops, and an important peak early in the autumn following the first rains. In the fresh soil samples, the soil inorganic-N levels decreased thereafter throughout the autumn, likely due to $\mathrm{N}$ uptake by weeds germinating following the first autumn rains, $\mathrm{N}$ uptake by olive trees and nitrate leaching. In incubated soil samples the inorganic-N levels persisted high during the autumn. Whether $\mathrm{N}$ is mineralized or immobilized greatly depends on the $\mathrm{C}: \mathrm{N}$ ratio of the organic residues being decomposed (Havlin et al., 2005; Rodrigues et al., 2006). The residues of the legume cover crops used in this experiment presented C: $\mathrm{N}$ ratios between 20.4 and 31.9 (Table 1). Within this range of $\mathrm{C}: \mathrm{N}$ ratio some equilibrium between mineralization and immobilization in the short-term would be expected (Paul and Clark, 1996; Havlin et al., 2005; Beegle et al., 2008). However, in this study, in particular in the Suçães experiment, it seems that net $\mathrm{N}$ mineralization had occurred over the short-term at appreciable rates (Fig. 2c).

In spring, the inorganic-N levels in the fresh soil samples of the Suçães experiment were low. In this situation one might think that weeds and olive trees have taken up the inorganic-N that was forming. However, the inorganic- $\mathrm{N}$ levels were also low in the incubated soil samples. Additionally, the soil inorganic-N levels in the plots of the legume species were not significantly different to those observed in the control plots. This suggests that the mineralization-immobilization turnover was balanced at that time, the net $\mathrm{N}$ mineralization being close to a nil value. Probably the organic substrate added to the soil from the residues of the cover crops would have been exhausted.

Total net $\mathrm{N}$ mineralized in the plots of the legume cover crops (Figs. 2c and 3c) was low in comparison to that expected taking into account the great amounts of $\mathrm{N}$ that were recovered in the phytomass of the legume cover crops. This may be due to $\mathrm{NH}_{3}$ volatilization from $\mathrm{N}$-rich legume cover crop residues. The decomposition of organic residues in the soil surface is usually associated with great $\mathrm{NH}_{3}$ volatilization losses (Janzen and McGinn, 1991; Robinson and Polglase, 2000; Francis et al., 2008). In this particular 
study, it seems that the inorganic-N appearing in the soil was the result of the mineralization of the roots of the legume species. Most of $\mathrm{N}$ of the aerial phytomass probably never entered the soil.

$\mathrm{N}$ released from cover crop residues had a slight but nevertheless positive effect on the olive yields and on tree crop growth. The trees of the unfertilized natural vegetation plot showed lower yields in comparison to the trees of the legume cover crops and also low trunk circumference increase in the trial of Carrascal. This slight beneficial effect of the legume cover crops on the performance of the trees was corroborated by the results of $\mathrm{N}$ concentration in the fruit and also in the leaves. A more prominent effect was, however, expected given the amount of $\mathrm{N}$ in aerial biomass of legume cover crops. The lower performance than the one expected from olive trees benefiting from legume mulches may be due to: low soil inorganic-N availability; and a weak and slow response of olive trees to soil available N (Fernández-Escobar et al., 2009; Rodrigues et al., 2011).

Comparing the different legume cover crops' abilities to release $\mathrm{N}$ into the soil, no major differences were found. However, from data obtained from the incubation technique and from the performance of the trees, it seems that the pasture legume residues released less $\mathrm{N}$ in the short-term, but the effect lasted longer. The main reason might be less $\mathrm{N}$ recovered in the first growing season and higher $\mathrm{C}: \mathrm{N}$ ratio in their tissues. It is necessary to note that lupine and hairy vetch were grown for only one season, while pasture legumes included a mixture of species that self-reseeded in the following autumn for a second growing season. This would have a significant impact on the trees through a higher competition for soil resources (water and nutrients) in the spring, and also due to a continued increase in soil fertility due to the $\mathrm{N}$ fixed in the second growing season.

The $\mathrm{N}$ applied as fertilizer in Suçães had an unexpectedly low effect on $\mathrm{N}$ nutritional status of trees and olive yield. Before the trial started, the farmer used to apply the fertilizers beneath the tree canopy. In this experiment, the $\mathrm{N}$ fertilizer was spread across the ground. Probably this form of fertilizer application increased the fraction of $\mathrm{N}$ taken up by weeds and thereby reducing $\mathrm{N}$ use efficiency by olive trees. As far as we know, this aspect has not previously been studied in olive orchards, but farmers apply the fertilizers below the tree canopy, where the root density is expected to be higher, to promote the nutrient use efficiency (Arrobas and Moutinho-Pereira, 2009).

The in situ incubation technique provided a good explanation on what was happening in the soil. The protection of soil cores from leaching and plant uptake and also the maintenance of similar conditions for microbial activity within and outside the tubes (Raison et al., 1987; Hook and Burke, 1995) are important aspects providing reliability to this methodology.

\section{Conclusions}

The legume cover crops increased the inorganic- $\mathrm{N}$ in the soil and consequently the $\mathrm{N}$ nutritional status of the trees and olive yields in comparison to the natural vegetation which was not fertilized. However, the effect on soil available $\mathrm{N}$ was slight and short-lived, taking into account the amount of $\mathrm{N}$ present in the phytomass when the mulches were established. The reduced efficiency of $\mathrm{N}$ from the phytomass in promoting olive yield and tree $\mathrm{N}$ nutritional status might be due to: (i) a great peak of net $\mathrm{N}$ mineralization early in the autumn which creates the conditions for $\mathrm{N}$ losses through leaching and denitrification due to the following autumn and winter rains and (ii) great losses of $\mathrm{N}$ through $\mathrm{NH}_{3}$ volatilization from the legume residues left on the ground as a mulch.

To use legume cover crops in a sustainable way in perennial tree crops, other forms of residue management should be sought. It seems that there is a need to balance the $\mathrm{C}: \mathrm{N}$ ratio of the phytomass to reduce the peak of mineralization in the autumn, possibly by using mixtures of legume and non-legume species as cover crops. In addition, mulching seems a very inefficient form of managing $\mathrm{N}$ rich cover crop residues. If a farmer is interested in using green manures to increase the soil fertility of his orchards, he should incorporate the biomass in the soil. However, to incorporate the residues, the farmer needs to till the soil which can damage the root system of the trees. A balanced approach would be the incorporation of the residues with a shallow tillage.

\section{Acknowledgements}

Supported by FEDER funds through the Operational Program for Competitiveness Factors - COMPETE and National Funds through FCT - Foundation on Science and Technology under the project PTDC/AGR-AAM/098326/2008. The authors thank Rita Diz, Ana Pinto and José Rocha for laboratorial assistance.

\section{References}

Arrobas, M., Moutinho-Pereira, J.M., 2009. Fertilização do olival. In: Rodrigues, M.A. Correia, C.M. (Eds.), Manual da Safra e contra Safra do Olival. IPB, Bragança, Portugal, pp. 21-39.

Beegle, D.B., Kelling, K.A., Schmitt, M.A., 2008. Nitrogen from animal manures. In: Schepers, J.S., Raun, W.R. (Eds.), Nitrogen in Agricultural Systems. Agronomy Monograph n ${ }^{\circ}$ 49. ASA, CSSA, SSSA, Madison, WI, USA, pp. 823-881.

Bhogal, A., Hatch, D.J., Shepherd, M.A., Jarvis, S.C., 1999. Comparison of methodologies for field measurements of net nitrogen mineralization in arable soils. Plant Soil 207, 15-28.

Burton, C.H., 2009. Reconciling the new demands for food production with environmental needs in the management of livestock wastes. Bioresour. Technol. 100 5399-5405.

Centner, T.J., 2011. Addressing water contamination from concentrated animal feeding operations. Land Use Pol. 28, 706-711.

De Varennes, A., Torres, M.O., Queda, C., Goss, M.J., Carranca, C., 2007. Nitrogen conservation in soil and crop residues as affected by crop rotation and soil disturbance under Mediterranean conditions. Biol. Fertil. Soils 44, 49-58.

Di Stefano, J.F., Gholz, H.L., 1986. A proposed use of ion-exchange resins to measure nitrogen mineralization and nitrification in intact soil cores. Commun. Soil Sci. Plant Anal. 17, 989-998.

Durán, J., Morse, J.L., Groffman, P.M., 2012. Comparison of in situ methods to measure $\mathrm{N}$ mineralization rates in forest soils. Soil Biol. Biochem. 46, 145-147.

Eno, C.F., 1960. Nitrate production in the field by incubating the soil in polyethylene bags. Soil Sci. Soc. Am. Proc. 24, 277-279.

Fernández-Escobar, R., Marin, L., Sánchez-Zamora, M.A., García-Novelo, J.M., MolinaSoria, C., Parra, M.A., 2009. Long-term effects of N fertilization on cropping and growth of olive trees and on $\mathrm{N}$ accumulation in soil profile. Eur. J. Agron. 31, 223-232.

Francis, D.D., Vigil, M.F., Mosier, A.R., 2008. Gaseous losses of nitrogen other than through denitrification. In: Schepers, J.S., Raun, W.R. (Eds.), Nitrogen in Agricultural Systems. Agronomy Monograph n ${ }^{\circ}$ 49. ASA, CSSA, SSSA, Madison, WI, USA, pp. 255-279.

Freeman, M., Uriu, K., Hartmann, H.T., 2005. Diagnosing and correcting nutrient problems. In: Sibbett, G.S., Ferguson, L. (Eds.), Olive Production Manual. , 2nd ed. University of California, Pulb 3353, Oakland, CA, pp. 75-82.

Gaiser, T., Bernard, M., Stahr, K., 1994. Nitrogen and carbon mineralization in cultivated acrisols and vertisols in a sub-humid tropical climate. Z. Pflanzenernahr. Bodenk. 157, 375-381.

Hatch, D.J., Jarvis, S.C., Philipps, L., 1990. Field measurements of nitrogen mineralization using soil core incubation and acetylene inhibition of nitrification. Plant Soil 124, 97-107.

Havlin, J.L., Beaton, J.D., Tisdale, S.L., Nelson, W.L., 2005. Soil Fertility and Fertilizers and Introduction to Nutrient Management, 7th ed. Pearson Prentice Hall, NJ, USA.

Hook, P.B., Burke, I.C., 1995. Evaluation of methods for estimating net nitrogen mineralization in a semiarid grassland. Soil Sci. Soc. Am. J. 59, 831-837.

Janzen, H.H., McGinn, S.M., 1991. Volatile loss of nitrogen during decomposition of legume green manure. Soil Biol. Biochem. 23, 291-297.

Jenkinson, D.S., Ayanaba, A., 1977. Decomposition of carbon-14 labeled plant material under tropical conditions. Soil Sci. Soc. Am. J. 41, 912-915.

Jones Jr., J.B., 2001. Laboratory Guide for Conducting Soil Tests and Plant Analysis. CRC Press, Boca Raton, USA.

Monaco, S., Sacco, D., Borda, T., Grignani, C., 2010. Field measurement of net nitrogen mineralization of manured soil cropped to maize. Biol. Fertil. Soils 46, 179-184.

Ott, R.L., Longnecker, M., 2001. An Introduction to Statistical Methods and Data Analysis. Duxbury, Pacific Grove, USA.

Paul, E.A., Clark, F.E., 1996. Soil Biology and Biochemistry, 2nd ed. Academic Press, San Diego, CA.

Raison, R.J., Connell, M.J., Khanna, P.K., 1987. Methodology for studying fluxes of soil mineral-N in situ. Soil Biol. Biochem. 19, 521-530. 
Raun, W.R., Schepers, J.S., 2008. Nitrogen management for improved use efficiency. In: Schepers, J.S., Raun, W.R. (Eds.), Nitrogen in Agricultural Systems. Agronomy Monograph $\mathrm{n}^{\circ}$ 49. ASA, CSSA, SSSA, Madison, WI, USA, pp. 675-693.

Robinson, M.B., Polglase, P.J., 2000. Volatilization of nitrogen from dewatered biosolids. J. Environ. Qual. 29, 1351-1355.

Rodrigues, M.A., 2004. An in situ incubation technique to measure the contribution of organic nitrogen to potatoes. Agronomie 24, 249-256.

Rodrigues, M.A., Ferreira, I.Q., Claro, A.M., Arrobas, M., 2012. Fertiliser recommendations for olive based upon nutrients removed in crop and pruning. Sci. Hortic. 142, 205-211.

Rodrigues, M.A., Pavão, F., Lopes, J.I., Gomes, V., Arrobas, M., Moutinho-Pereira, J., Ruivo, S., Cabanas, J.E., Correia, C.M., 2011. Olive yields and tree nutritional status during a four year period without nitrogen and boron fertilization. Commun. Soil Sci. Plant Anal. 42, 803-814.

Rodrigues, M.A., Pereira, A., Cabanas, J.E., Dias, L., Pires, J., Arrobas, M., 2006. Crops use-efficiency of nitrogen from manures permitted in organic farming. Eur. J. Agron. 25, 328-335.
Russelle, M.P., 2008. Biological dinitrogen fixation in agriculture. In: Schepers, J.S. Raun, W.R. (Eds.), Nitrogen in Agricultural Systems. Agronomy Monograph $\mathrm{n}^{\circ}$ 49. ASA, CSSA, SSSA, Madison, WI, USA, pp. 281-359.

Sims, J.T., Stehouwer, R.C., 2008. Recycling of nitrogen through land application of agricultural, municipal, and industrial by-products. In: Schepers, J.S., Raun, W.R. (Eds.), Nitrogen in Agricultural Systems. Agronomy Monograph n 49. Madison, WI, USA, ASA, CSSA, SSSA, pp. 759-821.

Stanford, G., Epstein, E., 1974. Nitrogen mineralization-water relations in soils. Soil Sci. Soc. Am. Proc. 38, 103-107.

Subler, S., Parmelee, R.W., Allen, M.F., 1995. Comparison of buried bag and PVC core methods for in situ measurements of nitrogen mineralization rates in an agricultural soil. Commun. Soil Sci. Plant Anal. 26, 2369-2381.

Walinga, I., van Vark, W., Houba, V., van der Lee, J., 1989. Soil and Plant Analysis: Part 7 - Plant Analysis Procedures. Wageningen Agricultural University, The Netherlands.

Wienhold, B.J., 2007. Comparison of laboratory methods and an in situ method for estimating nitrogen mineralization in an irrigated silt-loam soil. Commun. Soil Sci. Plant Anal. 38, 1721-1732. 